"This is the peer reviewed version of the following article: "Reusable shuttles for exchangeable functional cargos: reversibly assembled, magnetically powered organocatalysts for asymmetric aldol reactions", which has been published in final form at https://doi.org/10.1016/j.tet.2019.130592 . This article may be used for non-commercial purposes in accordance with https://www.elsevier.com/ data/promis misc/external-embargo-list.pdf “.

\title{
Reusable shuttles for exchangeable functional cargos: reversibly assembled, magnetically powered organocatalysts for asymmetric aldol reactions
}

Carolina Mendoza ${ }^{\mathrm{a}, \dagger}$, Augustin de la Croix ${ }^{\mathrm{a}}$, Paola Riente ${ }^{\mathrm{a}, \sharp}$, Lluís Llorens ${ }^{\mathrm{a}, \mathrm{b}}$, Javier de Mendoza ${ }^{\mathrm{a}, *}$ and Miquel A. Pericàs, ${ }^{\mathrm{a}, *}$

${ }^{a}$ Institute of Chemical Research of Catalonia (ICIQ), The Barcelona Institute of Science and Technology, Avgda. Països Catalans, 16. E-43007 Tarragona, Spain. Fax: +34 977920244; Tel: +34 977920243

${ }^{b}$ Departament de Química Inorgànica i Orgànica, Universitat de Barcelona, c/ Martí i Franqués 1-11, E-08028 Barcelona, Spain.

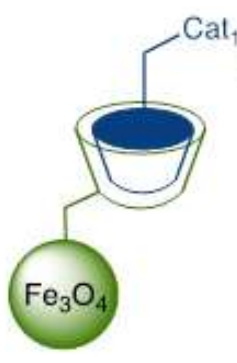

1) Use in catalysis

2) Disassembly

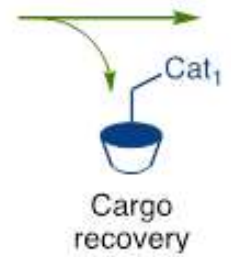

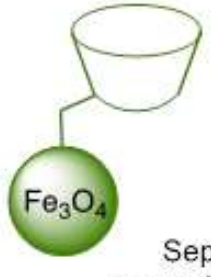

Separation by magnetic decantation
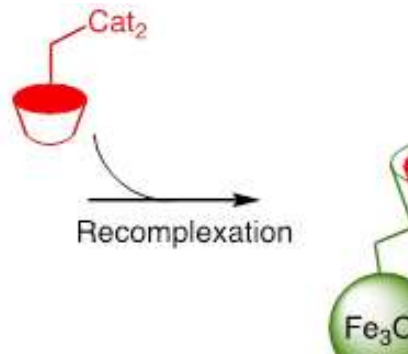

Reusable assembly

\section{ARTICLE INFO}

Article history:

Received

Received in revised form

Accepted

Available online

\section{Keywords:}

Aldol Reaction

Cyclodextrins

Nanoparticles

Organocatalysis

Recyclable Catalyst

Supramolecular Catalyst
ABSTRACT

A supramolecular approach has been followed to support adamantyl substituted proline organocatalysts onto the surface of magnetite nanoparticles decorated with a $\beta$-cyclodextrin motif. The resulting magnetic nanoparticles ( $c a . \sim 10 \mathrm{~nm}$ diameter) were used as modular, magnetically recyclable catalysts in the asymmetric aldol reaction of aromatic aldehydes with cyclic ketones in water. The catalytic assemblies can be easily dismantled in organic media, and the recovered nanoparticles (magnetically powered chemical shuttles) re-complexed with another suitably substituted catalytic unit (replaceable functional cargo).

2009 Elsevier Ltd. All rights reserved. 


\section{Introduction}

Shuttles have become popular in space exploration because they are (at least partially) reusable, thus significantly reducing the high cost of each mission. Similarly, chemical shuttles are desirable in a variety of areas, such as catalysis and drug delivery. In particular, shuttles are attractive when translocation, induced by an external physical or chemical stimulus, combines with function, such as a catalytic process, arising from another part of the molecule.

Immobilisation of asymmetric catalysts on non-soluble supports constitutes an attractive alternative to homogeneous catalysis, as it allows easy recovery and recycling. ${ }^{1}$ Thus, a wide variety of support types have been used, such as soluble and insoluble polymers, ${ }^{2}$ silica, ${ }^{3}$ dendrimers, ${ }^{4}$ as well as magnetic nanoparticles (MNPs). ${ }^{5}$ Among these supports, nanoparticles can present the additional advantages of increased catalytic activity, due to the accumulation of active centres on their surface, and to enhanced enantiocontrol, due to the close similarity with purely homogeneous processes. ${ }^{5 \mathrm{~b}, 6}$

Presumably, due to reasons such as the avoidance of catalyst leaching, minimization of product contamination and the possibility of recovery and reuse, catalyst immobilization by covalent tethering has become prevalent, although non-covalent attachment modes, such as encapsulation, adsorption or electrostatic interactions have also been explored. ${ }^{7}$ In any case, complex catalytic systems assembled by covalent immobilization suffer from important vulnerabilities arising from the nonapplicability of the shuttling principle. Thus, any failure in operation leads to the loss of the vehicle and its cargo.

Nowadays, the most versatile and readily available chemical shuttles are magnetite nanoparticles, displaying controllable mobility under the stimulus of an external magnetic field, due to their superparamagnetism. ${ }^{8}$ In addition, their outer surface, rich in hydroxyl groups can be readily functionalized by grafting with a variety of $\omega$-substituted 1,1,1-trialkoxysilanes. A variety of functional units have been incorporated on magnetic nanoparticles by this approach, most frequently using click chemistry (Fig. 1a). ${ }^{9}$

The vulnerability of the covalent approach mentioned above could be in principle overcome through the integration of highaffinity complexing units onto the magnetic nanoparticles surface. In this way, magnetically-powered chemical shuttles would be constructed, and functional cargos for different applications could be sequentially introduced by simple complexation-decomplexation-recomplexation sequences involving, for instance, the $\beta$-cyclodextrin-adamantyl supramolecular interaction (Fig. 1b). In addition to the increased versatility of this approach, any possible deactivation of the functional unit could be easily remediated by a solvent-induced disassembly of the non-covalent construct that would leave the valuable magnetically-powered shuttle ready for reuse through simple complexation with fresh catalytic units.

Although crown ethers and polyamines have been previously immobilised onto magnetic nanoparticles, ${ }^{10}$ we decided to focus on receptors with high affinities for organic molecules. This is the case for $\beta$-cyclodextrin (a naturally occurring cyclic array of seven D-glucopyranosyl subunits linked by $\alpha$-1,4-glycosidic bonds), which strongly binds adamantyl derivatives in water $\left(K_{\text {ass }}\right.$ $\left.=10^{5}-10^{6} \mathrm{M}^{-1}\right){ }^{11,12}$ Due to their low price, water solubility, lack of toxicity and highly hydrophobic internal cavities, cyclodextrins (CDs) have been widely exploited in the food, cosmetics and pharmaceutical industries ${ }^{13}$ When dissolved in an aqueous phase, the inner space of CDs provides a hydrophobic micro-environment. Thanks to this property, CDs have been widely employed as enzyme mimics ${ }^{14}$ and in catalysis, either covalently attached to chiral catalysts to act on an included substrate, ${ }^{15}$ or by complexing the catalyst inside the cavity to act on external substrates. ${ }^{16}$ Driving forces for inclusion into CDs are mainly van der Waals forces, hydrophobic interactions, electronic effects and steric factors. ${ }^{12 \mathrm{~b}, 17}$

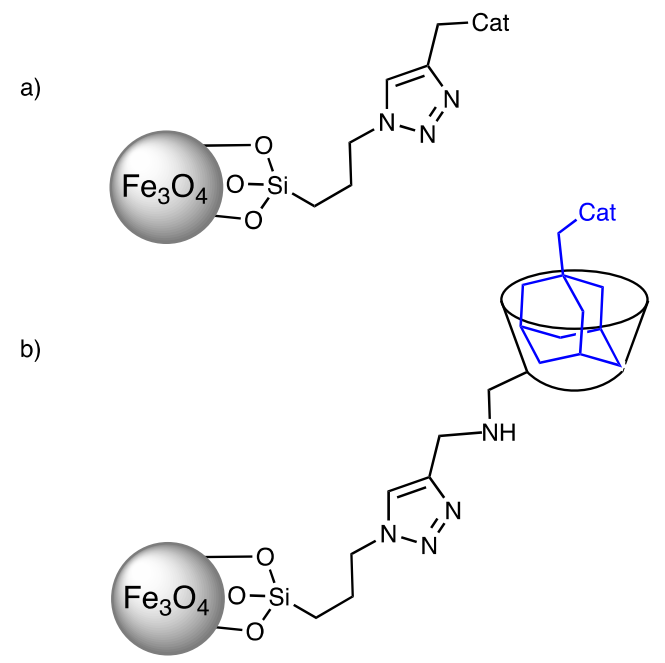

Figure 1. A single-purpose, magnetically powered catalyst (a) and a multipurpose, $\beta$-cyclodextrin-adamantyl reversibly assembled analogue designed to act as a chemical shuttle for a functional cargo (b).

CDs have also been attached to nanoparticles, for the adsorption of contaminants, ${ }^{18}$ drug delivery ${ }^{19}$ and catalysis. ${ }^{20}$ Kaifer and co-workers reported the preparation of water-soluble CD-modified gold nanospheres forming host-guest complexes with ferrocenemethanol and 1-adamantanol. ${ }^{21}$ Magnetic $\mathrm{Fe}_{\text {core }} \mathrm{Pt}_{\text {shell }}$ nanoparticles have also been modified with $\gamma$-CD (eight glucose subunits). The resulting water soluble nanoparticles have been employed as efficient catalysts for the aqueous hydrogenation of allyl alcohol ${ }^{22}$ and, quite recently, MNPs decorated with $\beta-C D$ were employed to recover an adamantyl-containing catalyst from the reaction medium. ${ }^{23}$ However, a magnetically-powered catalytic shuttle with a catalytic cargo based on the $\beta$-CD-adamantyl interaction has not yet been reported in the literature.

In this work we describe a supramolecular approach to catalysis with immobilized systems that benefits from both covalent tethering and non-covalent attachment strategies as key elements of the shuttle design. This is based on the introduction of a supramolecular motif (namely, a cyclodextrin-adamantane contact) as a reversible linker between the magnetic nanoparticles and the catalyst molecule. This could allow the easy recovery of a given catalyst from the surface of the nanoparticle for the sequential use of different catalysts with the same shuttle (Fig. 2) or even exploring the operation of tandem catalytic effects with the simultaneous presence of different catalysts on the shuttle. ${ }^{24}$ As a proof of concept for our design, we selected the proline catalysed aldol reaction between aromatic aldehydes and cyclohexanone in water. An adamantyl-decorated proline catalyst encapsulated into a $\beta$-CD has been reported by Liu and coworkers, ${ }^{16 \mathrm{~b}}$ yielding the corresponding hydroxyketones with high diastereo- and enantioselectivities. 


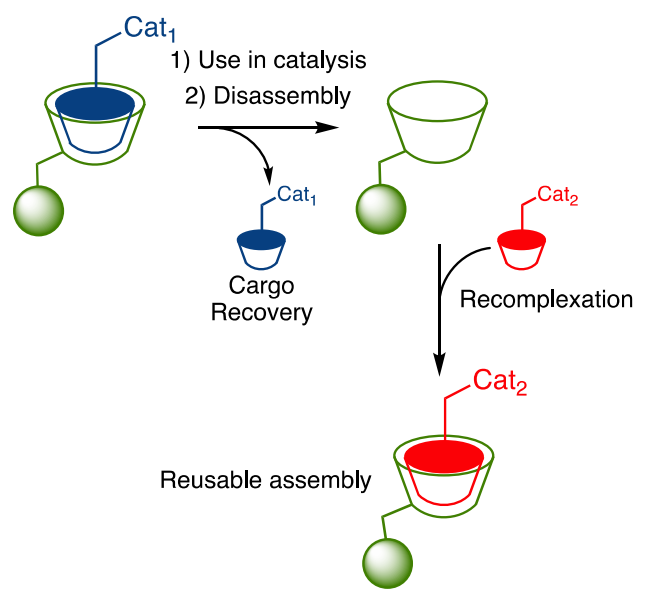

Figure 2. A multi-purpose, reversibly assembled magnetically powered catalyst for sequential use.

In our case, to attach the $\beta-C D$ to the magnetic nanoparticles, we decided to prepare functional nanoparticles 1 (Fig. 3) incorporating a 1,2,3-triazole subunit in the linker, which can be easily formed through a copper-catalysed alkyne-azide cycloaddition $(\mathrm{CuAAC})$ reaction, ${ }^{25}$ the best known example of click chemistry. ${ }^{26}$

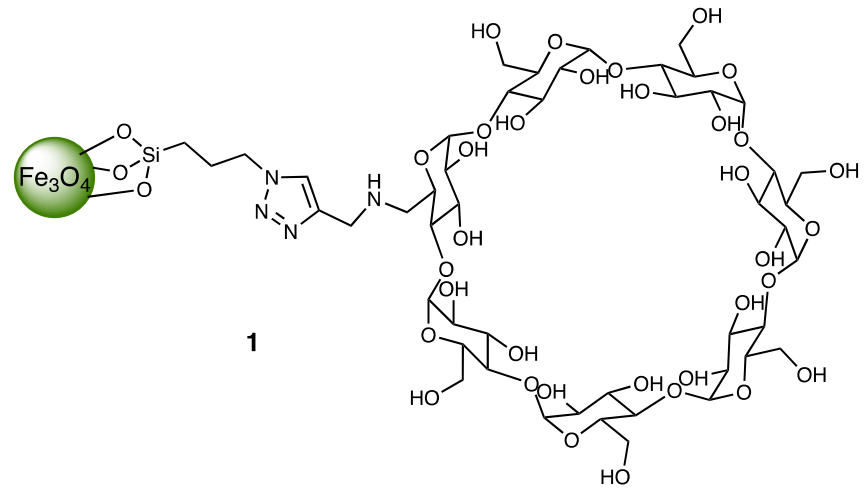

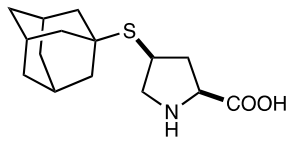

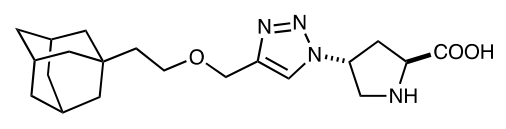

Figure 3. $\beta$-CD-functionalised MNPs (1) and partner L-hydroxyproline derivatives modified with adamantyl residues ( $\mathbf{2}$ and $\mathbf{3}$ ).

In recent years, we and other groups ${ }^{27}$ have studied and established the validity of this approach for the immobilisation of catalytic species without negative effects on either the catalytic activity or stereoselectivity. As part of the ongoing work in our group on the preparation of functional $\varepsilon$-cobalt ${ }^{28}$ and $\mathrm{Fe}_{3} \mathrm{O}_{4}{ }^{9 \mathrm{~d}-\mathrm{f}, 29 \mathrm{a}-}$ magnetic nanoparticles (MNPs) as easily recoverable and reusable catalysts, we decided to use azido-functionalised magnetite nanoparticles as platforms for the grafting of a monoalkynylated $\beta-C D$ subunit through a "click" cycloaddition reaction. Two organocatalytic guests $\mathbf{2}$ and $\mathbf{3}$ were explored, differing mainly in the nature and length of the linker between the proline catalytic unit and the adamantyl anchor. While $\mathbf{2}$ was designed to behave as a loose guest due to the short distance between the hydrophobic moiety and the catalytic site, we considered that $\mathbf{3}$, thanks to the longer linker connecting these two units, would lead to more tightly bound complexes with $\mathbf{1}$. According to this design, 2 would serve as a proof of principle for the recoverability and recyclability of $\mathbf{1}$ (the chemical shuttle) should its catalytic cargo be lost by leaching.

\section{Results and Discussion}

\subsection{Synthesis and characterization of the catalytic materials $8-9$ and 10-11}

MNPs of $\mathrm{Fe}_{3} \mathrm{O}_{4}$ (4) were prepared following the coprecipitation method, in the presence of oleic acid as a surfactant (Scheme 1). ${ }^{30}$ Transmission electron microscopy (TEM) images revealed the formation of $8.4 \pm 2.6 \mathrm{~nm}$ nanoparticles (Fig. 4a). Next, the 3-azidopropyl moiety was grafted onto the surface of the MNPs by reaction with 3-azidopropyltrimethoxysilane (5) in toluene, ${ }^{31}$ leading to $9.8 \pm 2.9 \mathrm{~nm}$ nanoparticles 6 (Fig. $4 \mathrm{~b}$ ) with a functionalization of approximately $0.30 \mathrm{mmol} \quad \mathrm{N}_{3} / \mathrm{g}$ (as determined by nitrogen elemental analysis).

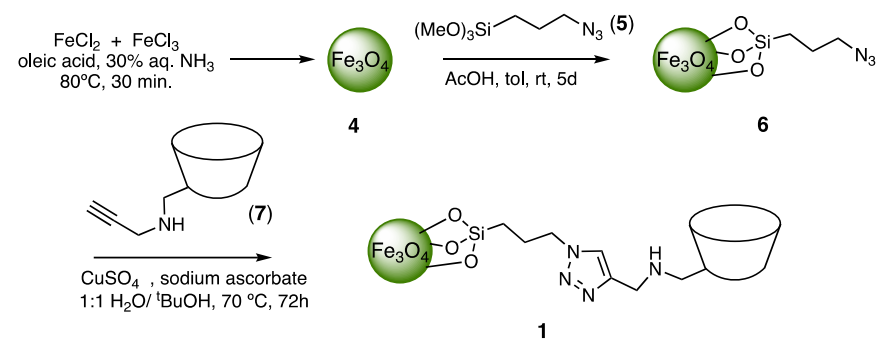

Scheme 1. Preparation of $\mathrm{Fe}_{3} \mathrm{O}_{4}$ MNPs 1 functionalised with $\beta$-CD.

Integration of the $\beta$-CD derivative $7^{32}$ onto the MNPs was carried out using a CuAAC reaction ${ }^{25 a-b}$ promoted by $\mathrm{CuSO}_{4}$ /sodium ascorbate, using a 1:1 water/t-butyl alcohol mixture as solvent. The reaction was monitored by IR spectroscopy (Fig. 5), and once the azide band of the functional nanoparticles (around $2097 \mathrm{~cm}^{-1}$ ) had disappeared, the particles 1 were separated by magnetic decantation. The incorporation of the $\beta-C D$ moiety was indicated by the presence of bands in the region of $900-1200 \mathrm{~cm}^{-1}$ associated with the $\mathrm{C}-\mathrm{O}$ bonds in the IR spectrum of 1 . The evolution of the shape and size of the functional nanoparticles, from $\mathbf{4}$ to $\mathbf{1}$ was followed by TEM micrography (Fig. 4a-c) Nanoparticles $\mathbf{1}$ were obtained as a mixture of small aggregates and discrete particles with a diameter of $10.3 \pm 2.9 \mathrm{~nm}$ (Fig. 4c), without significant change in the aspect or size with respect to precursors 4 and 6 . The degree of functionalisation of MNPs $\mathbf{1}$ was determined by elemental analysis $(\% \mathrm{~N})$ and found to have $\beta-\mathrm{CD}$ loadings of approximately $0.21 \mathrm{mmol} / \mathrm{g}$. 


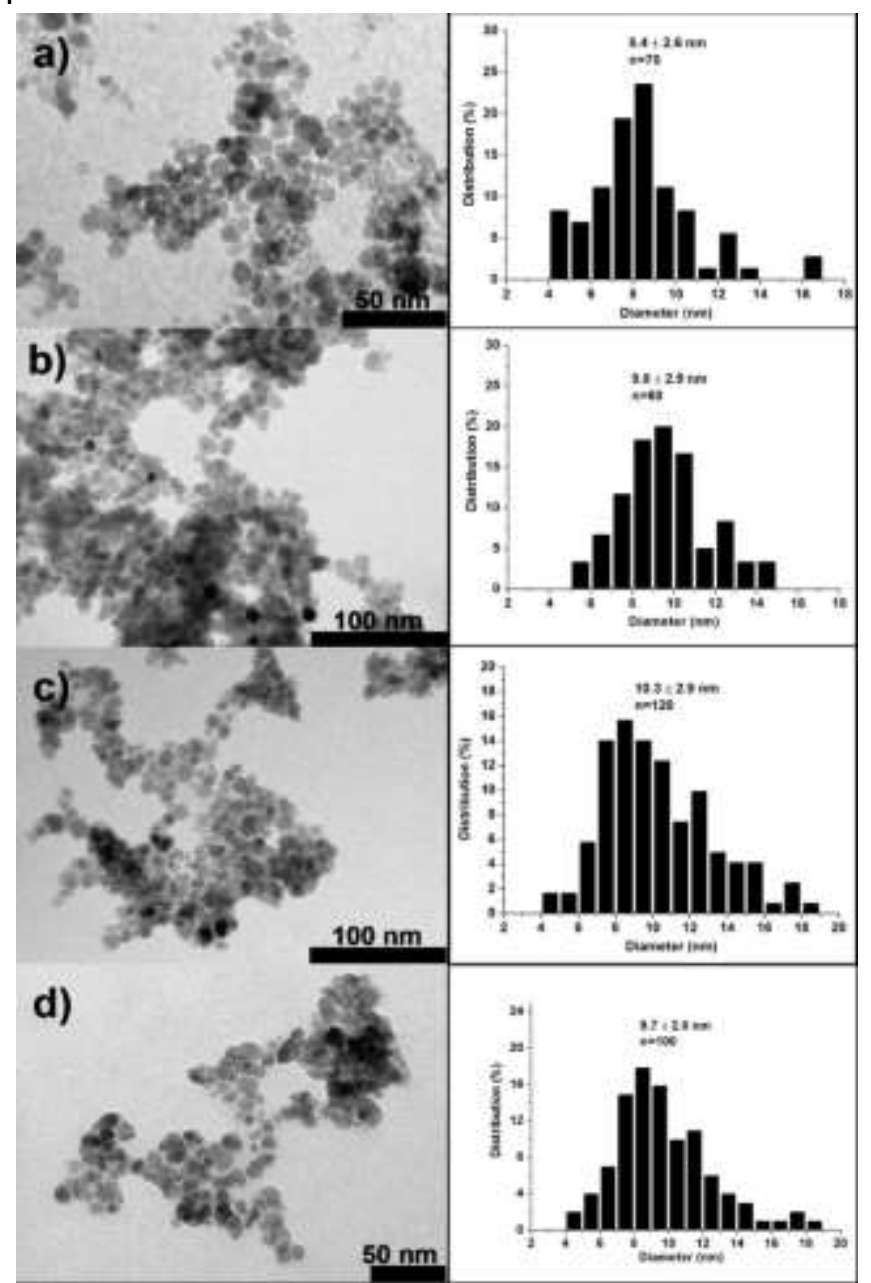

Figure 4. TEM image and size distribution of a) MNPs 4, b) azidefunctionalized MNPs 6, c) $\beta$-CD-functionalised MNPs 1 and d) MNPs 11.

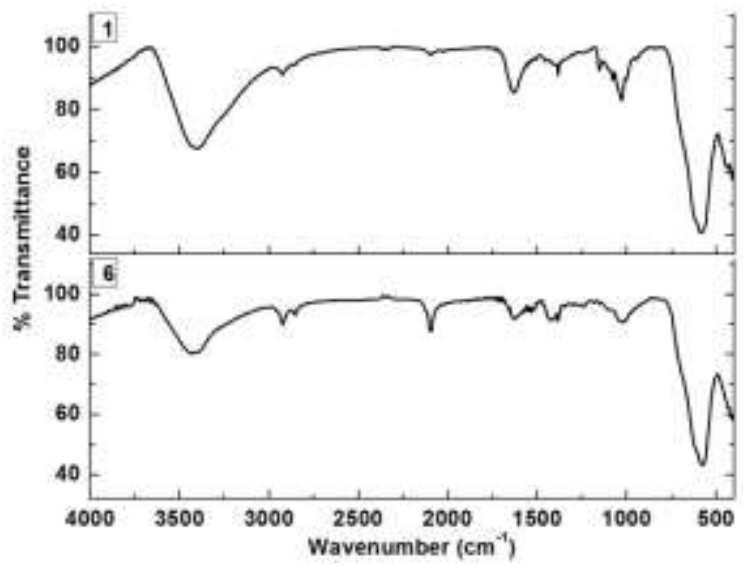

Figure 5. IR spectra of azide-functionalised MNPs 6 and $\beta$-CDfunctionalised MNPs $\mathbf{1}$.

To test the shuttling principle in catalysis, proline derivatives $\mathbf{2}$ and $\mathbf{3}$ (Fig. 3, see ESI for synthetic details) were first submitted to complexation with $\beta-\mathrm{CD}$ for comparative purposes (Scheme 2).

To this end, equimolar amounts of $\mathbf{2}$ or $\mathbf{3}$ and $\beta-\mathrm{CD}$ were dissolved in 95:5 water/methanol. The reaction mixture was stirred at room temperature for 2-48 h, and the solvent was then removed ununder reduced pressure to afford the corresponding complex 8 or 9 . Both ${ }^{1} \mathrm{H}$ NMR spectroscopy and MS provided evidence of the formation of the host-guest complexes (see ESI for NMR spectra). In the case of $\mathbf{8}$, TOF-MS (positive mode) shows a peak at $1438.3 \mathrm{amu}$ that was assigned to the cation $[\mathrm{M}+\mathrm{Na}]^{+}$, where $\mathrm{M}$ corresponds to the mass of the inclusion complex between $\beta$-CD and guest $2\left(\mathrm{C}_{57} \mathrm{H}_{93} \mathrm{~N}_{4} \mathrm{O}_{37} \mathrm{~S}\right)$. On the other hand, the TOF-MS spectrum (negative mode) of complex 9 shows a peak at $\mathrm{m} / \mathrm{z}=1507.3 \mathrm{amu}$, assigned to the anion $[\mathrm{M}-\mathrm{H}]^{-}$ where $\mathrm{M}$ is the mass of the inclusion complex between $\beta-\mathrm{CD}$ and guest 3.
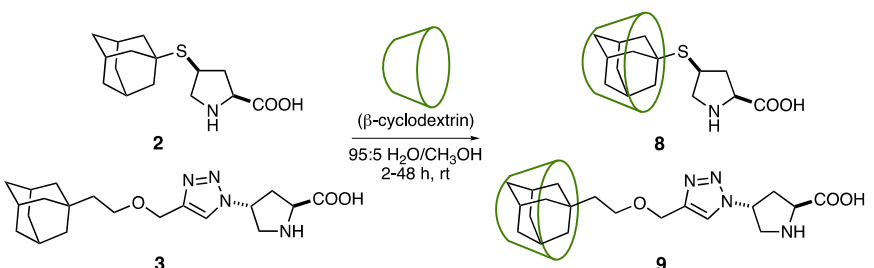

Scheme 2. Preparation of inclusion complexes of $\beta$-CD with L-proline derivatives $\mathbf{2}$ and $\mathbf{3}$.

Following the same procedure, proline derivatives $\mathbf{2}$ and $\mathbf{3}$ were immobilised onto the surface of the cyclodextrin-modified magnetite nanoparticles $\mathbf{6}$ to provide the shuttle+catalyst nanoparticle assemblies $\mathbf{1 0}$ and $\mathbf{1 1}$ (Fig. 6).

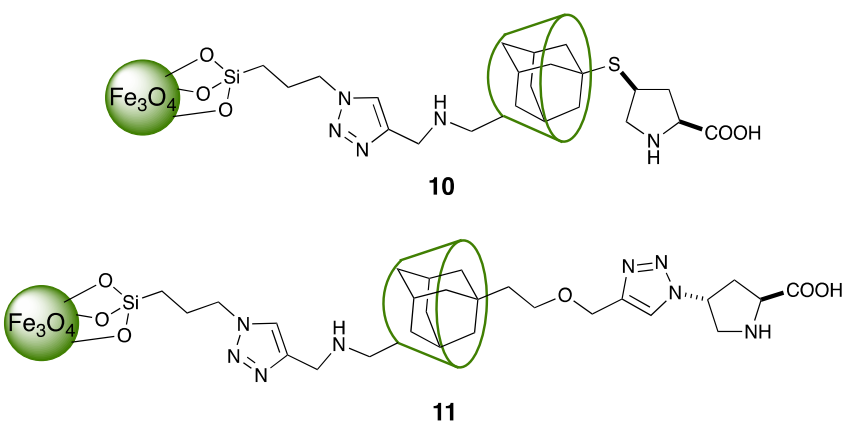

Figure 6. Fully assembled shuttle+catalyst nanoparticles $\mathbf{1 0}$ and $\mathbf{1 1}$.

TEM images (Fig. 4d) showed that the size of the nanoparticles was maintained $(9.1 \pm 2.2 \mathrm{~nm}$ for nanoparticles $\mathbf{1 0}$ and $9.7 \pm 2.8 \mathrm{~nm}$ for $\mathbf{1 1})$.

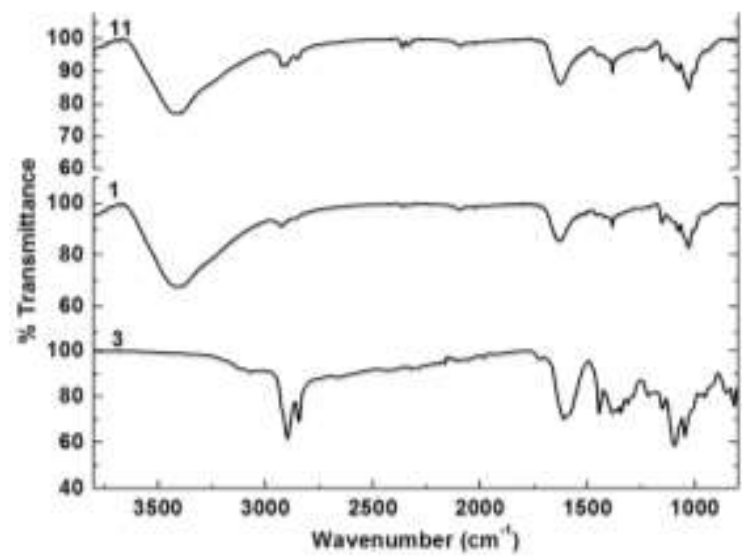

Figure 7. Comparison of the IR spectra of proline derivative $\mathbf{3}$, MNPs 1 and MNPs 11.

The appearance of an additional band at $2989 \mathrm{~cm}^{-1}$ in the IR spectrum of the assemblies (Fig. 7) supports the presence of the proline catalytic unit on the surface of the nanoparticles. Thermogravimetric analysis (Fig. 8), is also strongly indicative of the presence of the proline derivative on the surface of the nanoparticles. Thus, $25 \%$ of the initial weight is lost between 300 and $800{ }^{\circ} \mathrm{C}$ from nanoparticles $\mathbf{1 1}$, whereas a much lower weight 
loss is recorded for $\beta$-CD-functionalised nanoparticles $\mathbf{1}$ over the same temperature range.

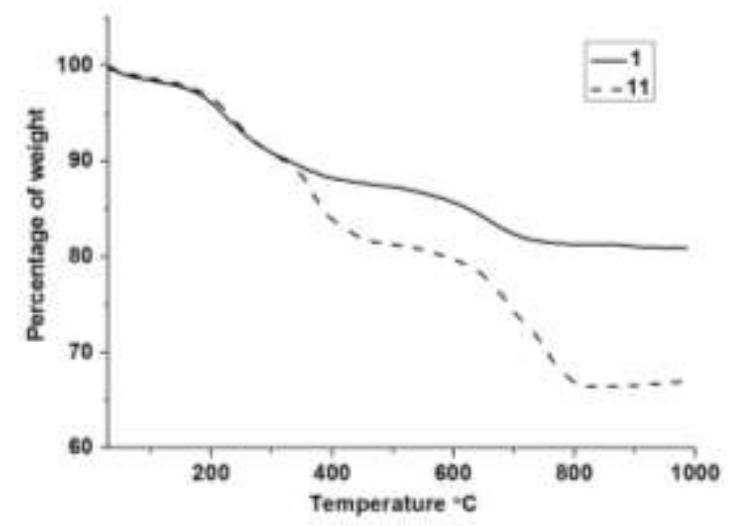

Figure 8. TGA curves showing the weight loss of nanoparticles $\mathbf{1 1}$ and $\mathbf{1}$ over the $300-800{ }^{\circ} \mathrm{C}$ temperature range.

\subsection{Catalytic behaviour of 2-3 and 8-9 in the asymmetric aldol reaction in water}

We first evaluated prolines $\mathbf{2 - 3}$ as catalysts in the model asymmetric aldol reaction of benzaldehyde (12a) and cyclohexanone (13) in water, using $10 \mathrm{~mol} \%$ of the catalyst (Table 1, entries 1 and 4). In both cases, moderate yields of the aldol product were obtained after 24 hours, with good to excellent enantioselectivities. In terms of diastereo- and enantioselectivity, the best results were recorded for catalyst $\mathbf{3}$ (>99\% ee). The scope of these catalysts for different aldehydes and ketones was examined under the same conditions (see ESI) leading to results that are comparable with those recorded with analogous 4-hydroxyproline derivatives. ${ }^{33}$ The $\beta$-CD complexes 8 and 9 were also tested for the same reaction using conditions analogous to the previous experiments $(10 \mathrm{~mol} \%$ of catalyst, 60 eq. of water and rt). Excellent stereoselectivities were observed for both catalysts (entries 6 and 7), although in the case of 8 a decrease in activity was observed with respect to the uncomplexed catalyst (compare entries 1 and 6). When catalyst 9 was allowed to react for 48 hours, a nearly complete conversion was achieved (compare entries 10 and 11). Overall, the results are very good both in terms of enantio- and diastereoselectivity. For catalyst 8 the enantioselectivity was improved for both 12a and $p$-trifluoromethylbenzaldehyde $(\mathbf{1 2 b})$. In the case of 9 the results were very similar to those obtained for the uncomplexed proline $\mathbf{3}$, both for $\mathbf{1 2 \mathbf { a }}$ and $\mathbf{1 2 b}$.

Table 1. Asymmetric aldol reaction of 12a-b and $\mathbf{1 3}$ using proline derivatives $\mathbf{2}$ and $\mathbf{3},{ }^{\text {a) }} \beta-\mathrm{CD}$ complexes $\mathbf{8}$ and $\mathbf{9},{ }^{\mathrm{b})}$ and functional nanoparticles $\mathbf{1 0}$ and $\mathbf{1 1}^{\mathrm{c})}$ as catalysts.

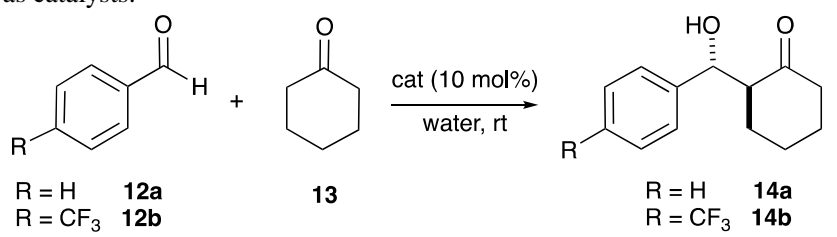

\begin{tabular}{cclllcl}
\hline Entry & Catalyst & $\mathrm{R}$ & $\begin{array}{l}\text { Time } \\
{[\mathrm{h}]}\end{array}$ & $\begin{array}{c}\text { Yield } \\
{[\%]^{\mathrm{d})}}\end{array}$ & $\begin{array}{c}\text { anti:syn } \\
\mathrm{e})\end{array}$ & $\begin{array}{c}\mathrm{ee}_{\text {anti }} \\
{[\%]^{\mathrm{f}}}\end{array}$ \\
\hline 1 & $\mathbf{2}$ & $\mathrm{H}$ & 24 & 26 & $6: 1$ & 85 \\
2 & $\mathbf{2}$ & $\mathrm{H}$ & 48 & 35 & $6: 1$ & 81 \\
3 & $\mathbf{2}$ & $\mathrm{CF}_{3}$ & 24 & 77 & $10: 1$ & 93 \\
4 & $\mathbf{3}$ & $\mathrm{H}$ & 24 & 41 & $18: 1$ & $>99$ \\
\hline
\end{tabular}

\begin{tabular}{cclllll}
\hline 5 & $\mathbf{3}$ & $\mathrm{CF}_{3}$ & 24 & 81 & $30: 1$ & 97 \\
6 & $\mathbf{8}$ & $\mathrm{H}$ & 24 & 13 & $4.5: 1$ & 94 \\
7 & $\mathbf{9}$ & $\mathrm{H}$ & 24 & 54 & $14: 1$ & 99 \\
8 & $\mathbf{8}$ & $\mathrm{CF}_{3}$ & 24 & 61 & $12: 1$ & 96 \\
9 & $\mathbf{8}$ & $\mathrm{CF}_{3}$ & 48 & 75 & $10: 1$ & 96 \\
10 & $\mathbf{9}$ & $\mathrm{CF}_{3}$ & 24 & 70 & $32: 1$ & 96 \\
11 & $\mathbf{9}$ & $\mathrm{CF}_{3}$ & 48 & 98 & $33: 1$ & 99 \\
$12^{\mathrm{g})}$ & $\mathbf{1 0}$ & $\mathrm{CF}_{3}$ & 24 & 32 & $9: 1$ & 92 \\
13 & $\mathbf{1 0}$ & $\mathrm{CF}_{3}$ & 72 & 49 & $9: 1$ & 91 \\
14 & $\mathbf{1 1}$ & $\mathrm{CF}_{3}$ & 72 & 90 & $13: 1$ & 87 \\
15 & $\mathbf{1 1}$ & $\mathrm{H}$ & 72 & 52 & $4: 1$ & 78 \\
\hline
\end{tabular}

${ }^{\mathrm{a}} \mathbf{2}$ or $\mathbf{3}(0.04 \mathrm{mmol}), \mathbf{1 2 a}-\mathbf{b}(0.4 \mathrm{mmol}), \mathbf{1 3}(2.0 \mathrm{mmol})$, water $(8$ mmol. ${ }^{\mathrm{b}} \mathbf{8}$ or $\mathbf{9}(0.032 \mathrm{mmol}), \mathbf{1 2 a}-\mathbf{b}(0.3 \mathrm{mmol}), \mathbf{1 3}(1.5 \mathrm{mmol})$, water $(18 \mathrm{mmol}){ }^{\mathrm{c}} \mathbf{1 0}$ or $\mathbf{1 1}(0.016-0.020 \mathrm{mmol}), \mathbf{1 2 a}-\mathbf{b}(0.2$ $\mathrm{mmol}), \mathbf{1 3}(1.0 \mathrm{mmol})$, water $(12 \mathrm{mmol}) .{ }^{\mathrm{d}}$ Isolated yield of the combined diastereoisomers. e Determined by ${ }^{1} \mathrm{H}$ NMR spectroscopy. ${ }^{\mathrm{f}}$ Determined by chiral HPLC. ${ }^{\mathrm{g}} \mathbf{1 2 b}(0.06 \mathrm{mmol})$, 13 (0.3 mmol), water (3.6 mmol).

\subsection{Testing the shuttling principle with 10-11. Recovery and reuse of the $M N P+\beta-C D$ shuttle}

For the catalytic study, functional nanoparticles $\mathbf{1 0}$ and $\mathbf{1 1}$ were suspended in water (60 eq.) and tested in the asymmetric aldol reaction of $p$-trifluoromethylbenzaldehyde (12b) with 13 (Table 1, entries 12-14). With nanoparticles 10, the aldol product was obtained in moderate yield (32\%) after 24 hours (entry 12) and, even after 72 hours, complete conversion was not achieved (entry 13). Although this clearly indicates a significant decrease in the activity of the catalyst upon complexation, in terms of diastereo- and enantioselectivity the results are perfectly comparable with those obtained with the free catalyst $\mathbf{2}$ and with the molecular complex $\mathbf{8}$. For catalyst $\mathbf{1 1}$ (entry 14) the reaction of $p$-trifluoromethylbenzaldehyde was achieved with excellent yield (90\%) after 72 hours reaction, but both diastereo- and enantioselectivities were eroded with respect to the reference, free catalyst 3 or its molecular complex 9.

As we have already mentioned, one of the main advantages associated with supporting a catalyst onto MNPs is the possibility of recovery by simple magnetic decantation and reuse. Through the assembling process, the magnetic properties of the supported nanoparticles are transmitted to the chiral catalyst they contain, becoming magnetically powered, and can be moved through a liquid phase or held within it by application of an external magnetic field. From the sustainability point of view, a catalyst loaded onto such a chemical shuttle can be separated from the reaction media and subsequently recovered and reused by magnetic decantation involving the simple application of inexpensive neodymium magnets to the walls of the reaction vessel. In addition, if decomplexation takes place upon repeated use or is provoked, for instance, by exposure of the complex to an organic medium, the most expensive part of the construct (the magnetic nanoparticles) can still be recovered by magnetic decantation and recomplexed (with either the same catalytic unit or with a different one) for further use.

To demonstrate the recyclability and reconfigurability of magnetic shuttle $\mathbf{1}$, freshly prepared $\mathbf{1 0}$ was first used as the catalyst in four consecutive runs of the aldol reaction between $p$ trifluoromethylbenzaldehyde and cyclohexanone (Table 2, entries 1-4). Indeed, while the enantioselectivity of the reaction remained constant during the recycling, the yield progressively decreased. This unsatisfactory result is due the poor solubility of the aldol product $\mathbf{1 4 b}$ in water, which requires the use of 
water/alcohol mixtures to separate the aldol product from the catalytic nanoparticles. While $\mathbf{1 0}$ is stable in water, the work-up is responsible for substantial leaching of the catalytic unit $\mathbf{2}$ and for the associated catalyst deactivation. Gratifyingly, the recovery of the unloaded shuttle $\mathbf{1}$ after the fourth reaction cycle was essentially quantitative. The recovered nanoparticles $\mathbf{1}$ were washed with THF to secure the removal of residual $\mathbf{2}$, dried under vacuum, and submitted to re-complexation with $\mathbf{3}$. Recycling of catalyst $\mathbf{1 1}$ assembled in this manner proved to be much more rewarding (entries 5-7). As could be anticipated from the design of the catalytic unit $\mathbf{3}$, involving a longer linker/spacer that improves the supramolecular interaction between the $\beta-C D$ and the adamantyl subunits, catalyst $\mathbf{1 1}$ behaves as a more stable entity under the employed reaction and work-up conditions, allowing multiple recycling without significant deterioration of the catalytic performance. In this manner, a proof of the shuttling principle has been established, although further work would be required to make this approach competitive with covalent-based catalyst immobilization.

Table 2. Recycling and reconfiguration of magnetic shuttle $\mathbf{1}$, from catalyst $\mathbf{1 0}$ to $\mathbf{1 1}$ in the aldol reaction of $\mathbf{1 2 b}$ with $\mathbf{1 3}$. $^{\mathrm{a}}$

\begin{tabular}{cccccc}
\hline Catalyst & Cycle & $\begin{array}{c}\text { Time } \\
{[\mathrm{h}]}\end{array}$ & $\begin{array}{c}\text { Yield } \\
{[\%]^{\mathrm{b}}}\end{array}$ & anti:syn $^{\mathrm{c}}$ & $\begin{array}{c}\mathrm{ee}_{\text {anti }} \\
{[\%]^{\mathrm{d}}}\end{array}$ \\
\hline $\mathbf{1 0}$ & 1 & 24 & 32 & $9: 1$ & 92 \\
& 2 & 24 & 17 & $9: 1$ & 93 \\
& 3 & 24 & Traces & $6: 1$ & 91 \\
& 4 & 24 & Traces & $6: 1$ & 92 \\
\hline \multirow{111}{*}{} & 5 & 72 & 89 & $14: 1$ & 89 \\
& 6 & 72 & 57 & $10: 1$ & 87 \\
& 7 & 72 & 35 & $5: 1$ & 85 \\
\hline
\end{tabular}

${ }^{\text {a }}$ Reaction conditions for catalyst 10: aldehyde $(0.2 \mathrm{mmol}), \mathbf{1 3}$ (1.0 mmol), water $(12 \mathrm{mmol})$, catalyst $(8-10 \mathrm{~mol} \%)$, room temperature, $24 \mathrm{~h}$; reaction conditions for catalyst 11: aldehyde $(0.2 \mathrm{mmol})$, ketone $(1.0 \mathrm{mmol})$, water $(12 \mathrm{mmol})$, catalyst $(8$ mol\%), room temperature, $72 \mathrm{~h}$. ${ }^{\mathrm{b}}$ Isolated yield of the combined diastereoisomers. ${ }^{\mathrm{c}}$ Determined by ${ }^{1} \mathrm{H}$ NMR spectroscopy. ${ }^{\mathrm{d}}$ Determined by chiral HPLC.

\section{Conclusion}

In summary, we have shown that superparamagnetic magnetite nanoparticles functionalised with $\beta$-cyclodextrin via click chemistry are suitable hosts for the non-covalent immobilization of L-proline derivatives bearing adamantyl residues. The resulting nanoparticles were used as magnetically recoverable catalysts in the asymmetric aldol reaction of aromatic aldehydes with cyclohexanone in water, displaying high diastereo- and enantioselectivities. We have also shown that the reversibly- assembled catalysts can be easily disassembled in organic media, and that the recovered functional nanoparticles (magnetically powered chemical shuttles) can be re-complexed with a different catalytic guest. This paves the way for the development of multipurpose catalytic kits assembled through non-covalent, yet strong hydrophobic interactions between magnetic nanoparticles decorated with suitable hosts (acting as chemical shuttles) and catalytic units equipped with complementary guests (as replaceable functional cargos).

\section{Experimental Section}

\subsection{General information}

Unless otherwise stated, all commercial compounds were used as received without any further purification. Ultra pure water was obtained from an SG Water Ultra clear basic system, that provides water with a conductivity at $25^{\circ} \mathrm{C}$ of $0.055 \mu \mathrm{S}$. NMR spectra were recorded on a Bruker Avance 400 Ultrashield NMR spectrometer at room temperature unless otherwise stated. For ${ }^{1} \mathrm{H}$ NMR all chemical shifts are reported in ppm relative to the proton resonance resulting from incomplete deuteration of the corresponding NMR solvent: $\mathrm{CD}_{3} \mathrm{OD}$ (3.31 ppm), $\mathrm{CDCl}_{3}$ (7.27 ppm) and $\mathrm{CD}_{2} \mathrm{Cl}_{2}$ (5.32 ppm). In the case of ${ }^{13} \mathrm{C}$ NMR spectra all chemical shifts are reported in $\mathrm{ppm}$ relative to the carbon resonance of the corresponding deuterated NMR solvent: $\mathrm{CD}_{3} \mathrm{OD}$ (49.15 ppm), $\mathrm{CD}_{2} \mathrm{Cl}_{2}$ (54 ppm) and $\mathrm{CDCl}_{3}$ (77.23 ppm). IR spectra were recorded on a Bruker Tensor 27 FTIR spectrometer fitted with an ATR cell. IR spectra of nanoparticles were recorded on a Thermo Nicolet 5700 FTIR spectrometer, using $\mathrm{KBr}$ pellets. Reactions under microwave irradiation were performed in a CEM Discover microwave synthesis apparatus using $10 \mathrm{~mL}$ vessels with septa for reactions performed at elevated temperatures and pressures. HPLC analyses were performed with Agilent Technologies HP-1100 or HP-1200 apparatus, equipped with UV detector or diode array detectors and MS detector respectively. Chiralcel OD-H $5 \mu \mathrm{m}(0.46 \mathrm{~cm} \times$ $25 \mathrm{~cm})$, Chiralpak AD-H $5 \mu \mathrm{m}(0.46 \mathrm{~cm} \times 25 \mathrm{~cm})$, Chiralpak ASH $5 \mu \mathrm{m}(0.46 \mathrm{~cm} \times 25 \mathrm{~cm})$, Chiralpak IC $5 \mu \mathrm{m}(0.46 \mathrm{~cm} \times 25$ $\mathrm{cm})$, Chiralpak IA $5 \mu \mathrm{m}(0.46 \mathrm{~cm} \times 25 \mathrm{~cm})$, Chiralpak IB $5 \mu \mathrm{m}$ $(0.46 \mathrm{~cm} \times 25 \mathrm{~cm})$ chiral columns fitted with guard columns were used to separate enantiomers. For the determination of the experimental conditions for the analysis, pure racemic samples were prepared and used as standards. Elemental analyses were performed at Servei de Microanàlisi de l'Institut d'Investigacions Químiques i Ambientals de Barcelona (IIQAB) or at Centro de Microanálisis Elemental, Departamento de Química Farmacéutica, Facultad de Farmacia de la Universidad Complutense de Madrid. Transmission electron microscopy (TEM) images were obtained with a JEOL JEM-1011 transmission electron microscope equipped with a lanthanum hexaboride filament operated at an acceleration voltage of 100 $\mathrm{kV}$. Thermogravimetric analysis were performed in a Mettler Toledo TGA/SDTA $851^{\mathrm{e}}$ thermo balance, working in a range of temperatures from room temperature to $1000^{\circ} \mathrm{C}$, with a precision of $\pm 0.25 \%$. TGA results in the product description were recorded under nitrogen stream $(80 \mathrm{~mL} / \mathrm{min})$ and with a heating rate of $10^{\circ} \mathrm{C} / \mathrm{min}$. Alumina crucibles of $100 \mu \mathrm{L}$ of capacity were used.

\subsection{Preparation of magnetite nanoparticles coated with oleic acid (4)}

These nanoparticles were prepared by slight modifications of a previously reported procedure. ${ }^{30}$ Iron(II) chloride tetrahydrate (99\%) (3.01 g, $15 \mathrm{mmol}$ ) and iron(III) chloride hexahydrate $(97 \%)(8.36 \mathrm{~g}, 30.0 \mathrm{mmol})$ were dissolved in degassed ultrapure water $(140 \mathrm{~mL})$ in a $500 \mathrm{~mL}$ round-bottomed flask and heated to $80{ }^{\circ} \mathrm{C}$, shaking vigorously with a shaker. Oleic acid (98\%) (2.1 mmol, $0.60 \mathrm{~g}, 0.68 \mathrm{~mL})$ dissolved in degassed acetone $(15 \mathrm{~mL})$ was added to the reaction mixture, followed by $30 \%$ aqueous $\mathrm{NH}_{3}$ solution $(18.2 \mathrm{~mL})$. After this addition, further amounts of oleic acid were added $(5 \times 1.0 \mathrm{~mL})$ over a 5 to 10 minutes period. The black reaction mixture was hold for 30 minutes at $80{ }^{\circ} \mathrm{C}$ and then slowly cooled to room temperature. A $1: 1 \mathrm{v} / \mathrm{v}$ mixture of methanol and acetone $(100 \mathrm{~mL})$ was then added to support the precipitation. After allowing the nanoparticles to settle overnight with the help of a magnet, the supernatant was separated using a cannula and the particles were washed with a $1: 1 \mathrm{v} / \mathrm{v}$ mixture of methanol and acetone $(5 \times 100 \mathrm{~mL})$. The nanoparticles were dried, first with an argon stream and then under vacuum. In this 
manner, $3.8 \mathrm{~g}$ of nanoparticles were isolated as a dark brown solid. Particle size $(\mathrm{n}=70, \mathrm{~nm}): 8.40(s=2.56)$; FT-IR $(\mathrm{KBr}): v$ 3453, 3005, 2956, 2923, 2852, 1632, 1426, 1409, 1261, 1229, $1100,1056,802,580 \mathrm{~cm}^{-1}$.

\subsection{Preparation of 3-azidopropyltrimethoxysilane (5)}

This compound was prepared by slight modifications of a previously reported procedure. ${ }^{31 \mathrm{a}}$ Sodium azide $95.5 \%$ (4.13 g, $60.7 \mathrm{mmol}$ ) was suspended in a mixture of anhydrous acetonitrile ( $80 \mathrm{~mL}$, molecular sieves $4 \AA$ ) and $2 \mathrm{~mL}$ DMF, under argon in a Schlenk flask. 3-iodopropyltrimethoxysilane $95 \%$ (5 mL, 24.3 mmol) was added with a syringe under stirring. The resulting white suspension was then stirred overnight at reflux. The reaction mixture was allowed to cool down to room temperature, the solvent was evaporated under reduced presure, dry pentane $(45 \mathrm{~mL})$ was added and the reaction mixture was stirred for 15 minutes. The pentane layer was transferred to another Schlenk flask using a cannula fitted with filter paper, a second addition of dry pentane was done and the process was repeated. The solvent was evaporated under reduced pressure to yield 5 (4.24 g, 20.7 mmol, $85 \%$ yield) as clear yellow liquid. All the spectroscopic data matched with those reported in the literature. ${ }^{[6]}{ }^{1} \mathrm{H}$ NMR $\left(400 \mathrm{MHz}, \mathrm{CDCl}_{3}\right): \delta 3.58\left(\mathrm{~s}, 9 \mathrm{H} \mathrm{CH} \mathrm{CH}_{3}\right), 3.27\left(\mathrm{t},{ }^{3} \mathrm{~J}(\mathrm{H}-\mathrm{H})=6.9\right.$ $\mathrm{Hz}, 2 \mathrm{H}), 1.77-1.67(\mathrm{~m}, 2 \mathrm{H}), 0.75-0.66 \mathrm{ppm}(\mathrm{m}, 2 \mathrm{H}) ;{ }^{13} \mathrm{C}$ NMR $\left(100 \mathrm{MHz}, \mathrm{CDCl}_{3}\right) \delta 53.9\left(\mathrm{CH}_{2}\right), 50.7\left(\mathrm{CH}_{3}\right), 22.7\left(\mathrm{CH}_{2}\right)$, 6.5 ppm $\left(\mathrm{CH}_{2}\right)$; FT-IR (ATR): $v$ 2942, 2841, $2094\left(\mathrm{~N}_{3}\right), 1457$, $1413,1344,1275,1241,1189,1079,883,816,628 \mathrm{~cm}^{-1}$.

\subsection{Azido-functionalised magnetite nanoparticles (6)}

These nanoparticles were prepared by slight modifications of a previously reported procedure. ${ }^{31 \mathrm{c}}$ In a typical preparation nanoparticles 4 (0.96 g) were dispersed by sonication (20 minutes) in about $480 \mathrm{~mL}$ of degassed toluene and then 3 azidopropyltrimethoxysilane $5(1.92 \mathrm{~g}, 9.33 \mathrm{mmol})$ was added, followed by glacial acetic acid $99.5 \%, d=1.05 \mathrm{~g} / \mathrm{mL}(0.192 \mathrm{~mL}$, $3.36 \mathrm{mmol})$ and ultrapure water $(0.269 \mathrm{~mL}, 14.93 \mathrm{mmol})$. The reaction mixture was stirred at room temperature for 3.5 days. The black particles were allowed to settle overnight with the help of an external magnet. The supernatant was separated using a cannula, and the nanoparticles were washed with toluene $(3 \times 42$ $\mathrm{mL})$ and methanol $(3 \times 26 \mathrm{~mL})$ and dried under vacuum. In this manner, $0.78 \mathrm{~g}$ of nanoparticles were recovered as a brown powder. According to the $\% \mathrm{~N}$ determined by elemental analysis the functionalization of the nanoparticles was $f=0.35 \mathrm{mmol}$ $\mathrm{N}_{3}$ /g. Particle size: $(\mathrm{n}=41, \mathrm{~nm}): 8.83(s=3.01)$; Found: C, 3.61; H, 0.80; N, 1.48; FT-IR (KBr): v 3442, 2955, 2924, 2852, 2098 $\left(\mathrm{N}_{3}\right), 1637,1420,1239,1182,1103,1022,585 \mathrm{~cm}^{-1}$.

\subsection{CuAAC reaction of alkyne (7) with azido-functionalised magnetite nanoparticles (6). Preparation of functional nanoparticles (1)}

Functional nanoparticles $6(0.1 \mathrm{~g}, f=0.283 \mathrm{mmol} / \mathrm{g}, 9.8 \pm 2.9$ $\mathrm{nm}$ diameter) were dispersed in $8 \mathrm{~mL}$ of a $1: 1$ mixture of ultrapure water and tert-butyl alcohol in a $100 \mathrm{~mL}$ round bottomed flask using ultrasonication for 20 minutes. Alkyne 7 $(0.066 \mathrm{~g}, 0.057 \mathrm{mmol})$ was added to the mixture, followed by the 1-sodium ascorbate $99 \%$ (7.85 $\mathrm{mg}, 0.040 \mathrm{mmol})$ and copper(II) sulfate pentahydrate $(0.919 \mathrm{mg}, 3.68 \mu \mathrm{mol})$ as a solid. The reaction mixture was stirred at $70{ }^{\circ} \mathrm{C}$ for 72 hours. Then the reaction was stopped and water was added to the reaction mixture. The particles were magnetically separated and washed as follows: water $(5 \mathrm{~mL}), 20 \% \mathrm{v} / \mathrm{v} \mathrm{NH}_{4} \mathrm{OH}$ in water $(2 \mathrm{~mL})$, water $(5 \mathrm{~mL})$ and methanol $(25 \mathrm{~mL})$. The particles were dried in vacuo at $40{ }^{\circ} \mathrm{C}$. The nanoparticles $(60 \mathrm{mg})$ were recovered as a brown solid. According to the $\% \mathrm{~N}$ determined by elemental analysis the functionalization of the nanoparticles was $f=0.123$ mmol/g. Particle size: $(\mathrm{n}=120, \mathrm{~nm}): 10.28(s=2.90)$; Found: $\mathrm{C}$, 4.35; H, 0.93; N, 0.69; FT-IR (KBr): v 3385, 2956, 2922, 2852, $1637,1399,1151,1079,1029,581 \mathrm{~cm}^{-1}$. TGA $\left(30-100{ }^{\circ} \mathrm{C}, 10\right.$ ${ }^{\circ} \mathrm{C} / \mathrm{min}$, under $\mathrm{N}_{2}$; for a $2.7370 \mathrm{mg}$ sample, \% weight loss): 13.3668 (left imit: $99.28^{\circ} \mathrm{C}$, right limit: $488.27^{\circ} \mathrm{C}$ ), 3.9734 (left limit: $488.27^{\circ} \mathrm{C}$, right limit: $847.22^{\circ} \mathrm{C}$ ).

4.6. Preparation of inclusion complexes of $\beta$-cyclodextrin with proline derivatives 2 and 3

\subsubsection{Inclusion complex of $\beta$-cyclodextrin and compound 2. Synthesis of complex 8}

$\beta$-Cyclodextrin $(0.206 \mathrm{~g}, 0.178 \mathrm{mmol})$ was placed in a $500 \mathrm{~mL}$ round-bottomed flask and was dissolved in water $(230 \mathrm{~mL})$ to give a colourless solution. To this solution, $2(0.050 \mathrm{~g}, 0.178$ mmol) dissolved in methanol $(12 \mathrm{~mL})$ was added and the mixture was stirred at room temperature for two days. After this time, the solvents were evaporated under reduced pressure and the solid residue was dried in vacuo for 5 hours to render the title product $8(0.219 \mathrm{~g}, 87 \%$ yield $)$ as a white solid. When the complexation time was shortened to 2 hours, yield was $76 \%$. ${ }^{1} \mathrm{H}$ NMR (400 $\left.\mathrm{MHz}, \mathrm{D}_{2} \mathrm{O}\right): \delta 5.11\left(\mathrm{~d},{ }^{3} \mathrm{~J}(\mathrm{H} 1, \mathrm{H} 2)=3.4 \mathrm{~Hz}, 7 \mathrm{H}, H 1 \beta-\mathrm{CD}\right), 4.17$ $(\mathrm{m}, 1 \mathrm{H}), 3.92(\mathrm{~m}, 28 \mathrm{H}, H 3 \beta-\mathrm{CD}+H 5 \beta-\mathrm{CD}+H 6 \beta-\mathrm{CD}), 3.71$ $\left(\mathrm{dd},{ }^{3} J(\mathrm{H} 2-\mathrm{H} 3)=9.8,{ }^{3} J(\mathrm{H} 1-\mathrm{H} 2)=3.4 \mathrm{~Hz}, 7 \mathrm{H}, H 2 \beta-\mathrm{CD}\right), 3.63$ $\left(\mathrm{t},{ }^{3} J(\mathrm{H}-\mathrm{H})=9.3 \mathrm{~Hz}, 7 \mathrm{H}, H 4 \beta-\mathrm{CD}\right), 3.56(\mathrm{~m}, 2 \mathrm{H}), 3.32-3.20$ $(\mathrm{m}, 1 \mathrm{H}), 2.80(\mathrm{~m}, 1 \mathrm{H}), 2.29(\mathrm{~m}, 3 \mathrm{H}, \mathrm{CH}$ adamantyl), $2.08-1.75$ ppm $\left(\mathrm{m}, 13 \mathrm{H}, 6 \times \mathrm{CH}_{2}\right.$ adamantyl $+\mathrm{CH}$ proline) ${ }^{13} \mathrm{C}$ NMR (101 $\left.\mathrm{MHz}, \mathrm{D}_{2} \mathrm{O}\right) \delta 176.09(\mathrm{COOH}), 104.92(\mathrm{CH}, \mathrm{C} 1 \beta-\mathrm{CD}), 84.14$ $(\mathrm{CH}, \mathrm{C} 4 \beta-\mathrm{CD}), 75.86(\mathrm{CH}, \mathrm{C} 3 \beta-\mathrm{CD}), 74.58(\mathrm{CH}, \mathrm{C} 2+\mathrm{C} 5 \beta-$ $\mathrm{CD}), 63.21(\mathrm{CH}), 62.64\left(\mathrm{CH}_{2}, \mathrm{C} 6 \beta-\mathrm{CD}\right), 56.83\left(\mathrm{CH}_{2}\right), 48.76(C)$, $46.67\left(\mathrm{CH}_{2}\right), 40.18(\mathrm{CH}), 38.45\left(\mathrm{CH}_{2}\right), 38.30\left(\mathrm{CH}_{2}\right), 31.71 \mathrm{ppm}$ $(C H)$. FT-IR (ATR): $v$ 3279, 2910, 2851, 1624, 1449, 1367, $1329,1299,1245,1152,1101,1079,1022,998,936 \mathrm{~cm}^{-1}$; MS (TOF MS ES+): $m / z$ (\%) $1438.3(12 \%)[\mathrm{M}+\mathrm{Na}]^{+}, 1157.2(37 \%)$ $[(\beta-\mathrm{CD})+\mathrm{Na}]^{+}, 304.1(100 \%)\left[\mathrm{C}_{15} \mathrm{H}_{23} \mathrm{NO}_{2} \mathrm{~S}+\mathrm{Na}\right]^{+}$.

\subsubsection{Inclusion complex of $\beta$-cyclodextrin and compound 3. Synthesis of complex 9}

$\beta$-cyclodextrin $(0.085 \mathrm{~g}, 0.073 \mathrm{mmol})$ was placed in a $250 \mathrm{~mL}$ round-bottomed flask and was dissolved in water $(94 \mathrm{~mL})$ to give a colourless solution. To this solution, compound $3(0.0275 \mathrm{~g}$, $0.073 \mathrm{mmol})$ dissolved in methanol $(7.1 \mathrm{~mL})$ was added and the mixture was stirred at room temperature for two hours. After this time, the solvents were eliminated using a rotary evaporator and the solid residue was dried in vacuo for 5 hours to render the title product $9(0.097 \mathrm{~g}, 88 \%$ yield $)$ as a white solid. ${ }^{1} \mathrm{H}$ NMR (400 $\left.\mathrm{MHz}, \mathrm{D}_{2} \mathrm{O}\right): \delta 8.17(\mathrm{~s}, 1 \mathrm{H}, \mathrm{H}$ triazole), $5.65-5.48(\mathrm{~m}, 1 \mathrm{H}), 5.10$ $\left(\mathrm{d},{ }^{3} J(\mathrm{H} 1-\mathrm{H} 2)=3.6 \mathrm{~Hz}, 7 \mathrm{H}\right), 4.68(\mathrm{~s}, 2 \mathrm{H}), 4.56(\mathrm{t}, J(\mathrm{H}-\mathrm{H})=8.8$ $\mathrm{Hz}, 1 \mathrm{H}), 4.03(\mathrm{~m}, 2 \mathrm{H}), 3.96-3.76(\mathrm{~m}, 30 \mathrm{H}), 3.75-3.53(\mathrm{~m}$, $17 \mathrm{H}), 3.00-2.62(\mathrm{~m}, 2 \mathrm{H}), 2.15(\mathrm{~s}, 3 \mathrm{H}), 1.79(\mathrm{~m}, 6 \mathrm{H}), 1.64(\mathrm{~s}$, $6 \mathrm{H}), 1.47 \mathrm{ppm}(\mathrm{t}, J(\mathrm{H}-\mathrm{H})=7.4 \mathrm{~Hz}, 2 \mathrm{H})$. FT-IR (ATR): v 3259, 2898, 2844, 1628, 1407, 1367, 1329, 1244, 1203, 1152, 1079, 1024, 998, 940, $846 \mathrm{~cm}^{-1}$; MS (TOF MS ES): $\mathrm{m} / \mathrm{z}(\%) 1507.3$ (52) $[\mathrm{M}-\mathrm{H}]^{-}\left(\mathrm{C}_{62} \mathrm{H}_{99} \mathrm{~N}_{4} \mathrm{O}_{38}\right.$ requires 1507.59), 1133.1 (20) $[(\beta-$ CD)-H]', 373.1 (100) $\left[\mathrm{C}_{20} \mathrm{H}_{29} \mathrm{~N}_{4} \mathrm{O}_{3}\right]^{-}$.

\subsection{Preparation of supramolecular complexes of functional magnetic nanoparticles 1 with proline derivatives $\mathbf{2}$ and $\mathbf{3}$}

\subsubsection{Catalytic magnetic nanoparticles 10}

Nanoparticles 1 ( $f=0.14 \mathrm{mmol} / \mathrm{g}, 1.27 \mathrm{~g}, 0.141 \mathrm{mmol})$ were suspended in ultrapure water $(278 \mathrm{~mL})$ to give a brown suspension with sonication for 10 minutes. Proline derivative 2 $(0.079 \mathrm{~g}, 0.282 \mathrm{mmol})$ was dissolved in methanol $(14 \mathrm{~mL})$ and was added to the nanoparticles dispersion. The mixture was stirred at room temperature for 48 hours. After this period, the nanoparticles were submitted to magnetic decantation, the 
supernatant was separated and the particles washed with methanol $(4 \times 20 \mathrm{~mL})$ to eliminate the excess of proline derivative 2. Next, the functional nanoparticles were dried under vacuum, first in the vacuum line and then overnight at $40{ }^{\circ} \mathrm{C}$ in a vacuum dessicator. In this manner, $1.18 \mathrm{~g}$ of nanoparticles were recovered. According to the $\% \mathrm{~N}$ determined by elemental analysis the functionalisation of the nanoparticles was $f=0.083$ mmol/g. Particle size: $(\mathrm{n}=32, \mathrm{~nm}): 9.08(s=2.23)$. Found: C, 6.34; H, 1.10; N, 0.58; S, 0.12. FT-IR (KBr): v 3425, 2956, 2923, $2853,1734,1636,1457,1080,1032,582 \mathrm{~cm}^{-1}$. TGA: $(30-1000$ ${ }^{\circ} \mathrm{C}, 10{ }^{\circ} \mathrm{C} / \mathrm{min}$, under $\mathrm{N}_{2}$; for a $4.0470 \mathrm{mg}$ sample, \% weight loss): 14.3850 (left limit: $111.05{ }^{\circ} \mathrm{C}$, right limit: 477.63 ), 6.6399 (left limit: $476.66^{\circ} \mathrm{C}$, right limit: 795.08 ), 7.2616 (left limit: 795.08 ${ }^{\circ} \mathrm{C}$, right limit: 923.61)

\subsubsection{Solvent-induced disassembly of functional magnetite nanoparticles 10}

Nanoparticles $\mathbf{1 0}(0.30 \mathrm{~g})$ were suspended in anhydrous THF and stirred at room temperature for 2 hours. After this period, the nanoparticles were submitted to magnetic decantation, the supernatant was separated and the particles washed with anhydrous THF $(5 \mathrm{~mL})$. The organic phases were combined and evaporated under vacuum to afford amino acid 2 (7.4 mg, quantitative recovery) as an oil. The recovered nanoparticles were identical to MNPs 1 by IR.

\subsubsection{Preparation of functional nanoparticles 11}

Nanoparticles 1 ( $f=0.13 \mathrm{mmol} / \mathrm{g}, 1.02 \mathrm{~g}, 0.146 \mathrm{mmol})$ were suspended in ultrapure water $(100 \mathrm{~mL})$ to give a brown suspension. The suspension was sonicated for 10 minutes, to ensure the dispersion of the nanoparticles. Proline derivative 3 $(0.104 \mathrm{~g}, 0.277 \mathrm{mmol})$ was dissolved in $160 \mathrm{~mL}$ water with sonication and heating and was added to the nanoparticles dispersion. The mixture was stirred at room temperature for 48 hours. After this period the nanoparticles were magnetically separated and washed with water $(5 \times 30 \mathrm{~mL})$ to eliminate the excess of proline derivative $\mathbf{3}$. The solid material was dried under vacuum, first in the vacuum line and then overnight at $40{ }^{\circ} \mathrm{C}$ in a vacuum dessicator. In this manner $0.941 \mathrm{~g}$ of nanoparticles were recovered as a brown solid. According to the $\% \mathrm{~N}$ determined by elemental analysis the functionalization of the nanoparticles was $f$ $=0.094 \mathrm{mmol} / \mathrm{g}$. Particle size: $(\mathrm{n}=101, \mathrm{~nm}): 9.72(s=2.80)$. Found: C, 6.52; H, 1.09, N, 1.05. FT-IR (KBr): v 3417, 2956, $2923,2898,2841,1635,1154,1080,1029,584 \mathrm{~cm}^{-1}$. TGA (30 $1000{ }^{\circ} \mathrm{C}, 10{ }^{\circ} \mathrm{C} / \mathrm{min}$, under $\mathrm{N}_{2}$; for a $4.7600 \mathrm{mg}$ sample, $\%$ weight loss): 8.0172 (left limit: $129.34^{\circ} \mathrm{C}$, right limit: $318.32^{\circ} \mathrm{C}$ ), 9.5587 (left limit: $320.27{ }^{\circ} \mathrm{C}$, right limit: $555.09^{\circ} \mathrm{C}$ ), 7.2616 (left limit: $555.09^{\circ} \mathrm{C}$, right limit: $719.23{ }^{\circ} \mathrm{C}$ ), 7.0041 (left limit: $719.23{ }^{\circ} \mathrm{C}$, right limit: $879.13{ }^{\circ} \mathrm{C}$ ).

\subsection{Procedures for the asymmetric aldol reactions catalysed by} $\beta$-cyclodextrin complexes

\subsubsection{With monomeric catalysts 8 and 9}

The catalyst 8 or $9(0.032 \mathrm{mmol}, 0.1 \mathrm{eq})$ was added to a suspension of the aldehyde $12(0.3 \mathrm{mmol})$ and cyclohexanone 13 (155 $\mu \mathrm{L}, 1.5 \mathrm{mmol}, 5 \mathrm{eq})$ in water $(324 \mu \mathrm{L}, 18 \mathrm{mmol}, 60 \mathrm{eq})$. The reaction mixture was stirred for 24-48 hours at room temperature. After that, water $(5 \mathrm{~mL})$ was added and the aqueous layer was extracted with ethyl acetate $(3 \times 5 \mathrm{~mL})$. The organic layer was dried with $\mathrm{MgSO}_{4}$, filtered and concentrated in vacuo. The crude product was purified by silica gel column chromatography using 9:1 hexane-ethyl acetate as eluent.

\subsubsection{With functional magnetic nanoparticles 10} and 11

The nanoparticles supported catalyst $\mathbf{1 0}$ or $\mathbf{1 1}(8-10 \mathrm{~mol} \%)$ was suspended in water $(216 \mu \mathrm{L}, 12 \mathrm{mmol}, 60 \mathrm{eq})$. Then to the suspension were added the aldehyde $12(0.2 \mathrm{mmol})$ and cyclohexanone 13 (104 $\mu \mathrm{L}, 1.0 \mathrm{mmol}, 5 \mathrm{eq})$. The reaction mixture was stirred at room temperature for 24-72h. Upon reaction, water $(2 \mathrm{ml})$ and $\mathrm{MeOH}(3 \mathrm{ml})$ were subsequently added and the mixture was separated by magnetic decantation of the nanoparticles. The magnetic nanoparticles were subsequently rinsed with water $(3 \mathrm{ml})$ and the aqueous layer together with the $\mathrm{MeOH}$ were extracted with ethyl acetate $(3 \times 5 \mathrm{~mL})$. The organic layer was dried with anhydrous $\mathrm{MgSO}_{4}$, filtrated and concentrated under reduced pressure. The crude product was purified by silica gel column chromatography using 9:1 hexaneethyl acetate as eluent. The nanoparticles were then vortexed with additional water, decanted, dried and reused. To exchange the adsorbed catalyst, the magnetic nanoparticles were vortexed in THF (3 x $3 \mathrm{~mL})$, magnetically decanted, rinsed with $\mathrm{MeOH}$, water, and dried.

\section{Dedication}

This paper is warmly dedicated to Professor Stephen G. Davies, to honor his long standing commitment as an author and an editor in favor of asymmetric synthesis and asymmetric catalysis.

\section{Acknowledgements}

This work was funded by CERCA Programme-Generalitat de Catalunya and MINECO (grant CTQ2015-69136-R and Severo Ochoa Excellence Accreditation 2014-2018 [SEV-2013-0319]). C.M. thanks AGAUR for a predoctoral fellowship.

\section{References}

1. Trindade, A. F.; Gois, P. M. P.; Afonso, C. A. M. Chem. Rev. 2009, 109, 418-514.

2. a) Clot-Almenara, L.; Rodríguez-Escrich, C.; OsorioPlanes, L.; Pericàs, M. A. ACS Catalysis 2016, 6, 7647 7651; b) Izquierdo, J.; Pericàs, M. A. ACS Catalysis 2016, 6, 348-356; c) Sagamanova, I. K.; Sayalero, S.; Martinez-Arranz, S.; Albeniz, A. C.; Pericas, M. A. Catalysis Science \& Technology 2015, 5, 754-764; d) Clark, J.; Mcquarrie, D., Eds. Handbook of Green Chemistry \& Technology; Blackwell Publ.: London, 2002; e) Leadbeater, N. E.; Marco, M. Chem. Rev. 2002, 102, 3217-3274; f) McNamara, C. A.; Dixon, M. J.; Bradley, M. Chem. Rev. 2002, 102, 3275-3300; g) Buchmeiser, M. R., Ed. Polymeric materials in organic synthesis and catalysis; Wiley-VCH: Weinheim, 2003; h) Benaglia, M.; Puglisi, A.; Cozzi, F. Chem. Rev. 2003, 103, 3401-3429; i) Haag, R.; Roller, S. In Top. Curr. Chem.; Kirsching, A. Ed.; Springer: Heidelberg, 2004; j) Toy, P. H.; Shi, M. Tetrahedron 2005, 61, 12013; k) Dioos, B. M. L.; Vankelecom, I. F. J.; Jacobs, P. A. Adv. Synth. Catal. 2006, 348, 1413-1446; 1) Cozzi, F. Adv. Synth. Catal. 2006, 348, 1367-1390; m) Itsuno, S.; Haraguchi, N. In Handbook of Asymmetric Heterogeneous Catalysis; Ding, K.; Uozumi, Y. Eds.; Wiley-VCH: Weinheim, 2008; n) Benaglia, M., Ed. Recoverable and Recyclable Catalysts; John Wiley \& 
Sons: Chichester, 2009; o) Lu, J.; Toy, P. H. Chem. Rev. 2009, 109, 815-838; p) Kristensen, T. E.; Hansen, T. Eur. J. Org. Chem. 2010, 2010, 3179-3204.

3. a) Han, B.; Zhao, L.; Song, Y.; Zhao, Z.; Yang, D.; Liu, R.; Liu, G. Catalysis Science \& Technology 2018, 8, 2920-2927; b) Zamboulis, A.; Moitra, N.; Moreau, J. J. E.; Cattoen, X.; Wong Chi Man, M. J. Mater. Chem. 2010, 20, 9322-9338; c) Trewyn, B. G.; Hung-Ting, C.; Lin, V. S.-Y. In Recoverable and Recyclable Catalysts; Benaglia, M. Ed.; Wiley \& Sons, Ltd., 2009; d) Zhao, Y.; Jin, R.; Chou, Y.; Li, Y.; Lin, J.; Liu, G. RSC Advances 2017, 7, 22592-22598.

4. a) Wu, L.; Liu, J.; Ma, B.; Fan, Q. In Bridging Heterogeneous and Homogeneous Catalysis; Can, L.; Yan, L. Eds.; Wiley VCH: Weinheim, 2014; b) Helms, B.; Fréchet, J. M. J. Adv. Synth. Catal. 2006, 348, 11251148.

5. a) Sreenivasarao, P.; Debasish, D.; Jyotirmayee, D. $A d v$. Synth. Catal. 2013, 355, 3532-3538; b) Jimeno, C.; Sayalero, S.; Pericàs, M. A. In Heterogenized Homogeneous Catalysts for Fine Chemicals Production. Catalysis by Metal Complexes; Barbaro, P.; Liguori, F. Eds.; Springer: Heidelberg, 2010; p. 123; c) Zaera, F. Chem. Soc. Rev. 2013, 42, 2746-2762; d) Dalpozzo, R. Green Chem. 2015, 17, 3671-3686; e) Wang, D.; Astruc, D. Chem. Rev. 2014, 114, 6949-6985.

6. Laurent, S.; Forge, D.; Port, M.; Roch, A.; Robic, C.; Elst, L. V.; Muller, R. N. Chem. Rev. 2008, 108, 20642110.

7. a) Zhi-Huai, L.; Zhi-Ming, Z.; Xiao-Yan, H.; Jun, Z.; Xiao, D.; Ying-Qiang, L. Chirality 2012, 24, 1092-1095; b) Fraile, J. M.; García, J. I.; Mayoral, J. A. Chem. Rev. 2008, 109, 360-417.

8. a) Stevens, P. D.; Li, G.; Fan, J.; Yen, M.; Gao, Y. Chem. Commun. 2005, 4435-4437; b) Abu-Reziq, R.; Alper, H.; Wang, D.; Post, M. L. J. Am. Chem. Soc. 2006, 128, 5279-5282; c) Kawamura, M.; Sato, K. Chem. Commun. 2006, 4718-4719; d) Shylesh, S.; Schünemann, V.; Thiel, W. R. Angew. Chem. 2010, 122, 3504-3537; e) Shylesh, S.; Schünemann, V.; Thiel, W. R. Angew. Chem. Int. Ed. 2010, 49, 3428-3459.

9. a) Luo, S. Z.; Zheng, X. X.; Cheng, J. P. Chem. Commun. 2008, 5719-5721; b) Schatz, A.; Hager, M.; Reiser, O. Adv. Funct. Mater. 2009, 19, 2109-2115; c) Wang, B. G.; Ma, B. C.; Wang, Q. O.; Wang, W. Adv. Synth. Catal. 2010, 352, 2923-2928; d) Riente, P.; Yadav, J.; Pericàs, M. A. Org. Lett. 2012, 14, 3668-3671; e) Riente, P.; Mendoza, C.; Pericàs, M. A. J. Mater. Chem. 2011, 21, 7350-7355; f) Ranjbar, S.; Riente, P.; Rodríguez-Escrich, C.; Yadav, J.; Ramineni, K.; Pericàs, M. A. Org. Lett. 2016, 18, 1602-1605; g) Myung- Jong, J.; Dong- Hwan, L. Angew. Chem. 2010, 122, 1137-1140.

10. Mendoza, C.; Jansat, S.; Vilar, R.; Pericas, M. A. RSC Advances 2015, 5, 87352-87363.

11. Ueno, A. Supramol. Sci. 1996, 3, 31-36.

12. a) Szejtli, J. Chem. Rev. 1998, 98, 1743-1753; b) Hapiot, F.; Tilloy, S.; Monflier, E. Chem. Rev. 2006, 106, 767781.

13. Hedges, A. R. Chem. Rev. 1998, 98, 2035-2044.

14. a) Breslow, R.; Doherty, J. B.; Guillot, G.; Lipsey, C. J. Am. Chem. Soc. 1978, 100, 3227-3229; b) Anslyn, E.; Breslow, R. J. Am. Chem. Soc. 1989, 111, 5972-5973; c) Anslyn, E.; Breslow, R. J. Am. Chem. Soc. 1989, 111,
8931-8932; d) Breslow, R.; Dong, S. D. Chem. Rev. 1998, 98, 1997-2011.

15. a) Schlatter, A.; Kundu, M. K.; Woggon, W. D. Angew. Chem. Int. Ed. 2004, 43, 6731-6734; b) Schlatter, A.; Kundu, M. K.; Woggon, W.-D. Angew. Chem. 2004, 116, 6899-6902.

16. a) Qi, M.; Tan, P. Z.; Xue, F.; Malhi, H. S.; Zhang, Z.-X.; Young, D. J.; Hor, T. S. A. RSC Advances 2015, 5, 35903596; b) Liu, K.; Haeussinger, D.; Woggon, W. D. Synlett 2007, 2298-2300; c) Shen, Z. X.; Ma, J. M.; Liu, Y. H.; Jia, C. J.; Li, M.; Zhang, Y. W. Chirality 2005, 17, 556558.

17. Rekharsky, M. V.; Inoue, Y. Chem. Rev. 1998, 98, 18751917.

18. a) Fuhrer, R.; Herrmann, I. K.; Athanassiou, E. K.; Grass, R. N.; Stark, W. J. Langmuir 2011, 27, 1924-1929; b) Kang, Y.; Zhou, L. L.; Li, X.; Yuan, J. Y. J. Mater. Chem. 2011, 21, 3704-3710; c) Badruddoza, A. Z. M.; Tay, A. S. H.; Tan, P. Y.; Hidajat, K.; Uddin, M. S. J. Hazard. Mater. 2011, 185, 1177-1186.

19. a) Banerjee, S. S.; Chen, D.-H. Chem. Mater. 2007, 19, 6345-6349; b) Banerjee, S. S.; Chen, D. H. J. Nanopart. Res. 2009, 11, 2071-2078.

20. a) Kiasat, A. R.; Nazari, S. J. Mol. Catal. A: Chem. 2012, 365, 80-86; b) Kaboudin, B.; Mostafalu, R.; Yokomatsu, T. Green Chem. 2013, 15, 2266-2274; c) Senra, J. D.; Malta, L. F. B.; da Costa, M.; Michel, R. C.; Aguiar, L. C. S.; Simas, A. B. C.; Antunes, O. A. C. Adv. Synth. Catal. 2009, 351, 2411-2422.

21. Liu, J.; Ong, W.; Roman, E.; Lynn, M. J.; Kaifer, A. E. Langmuir 2000, 16, 3000-3002.

22. Mori, K.; Yoshioka, N.; Kondo, Y.; Takeuchi, T.; Yamashita, H. Green Chem. 2009, 11, 1337-1342.

23. a) Li, Q.; Li, Y.; Wang, J.; Lin, Y.; Wei, Z.; Duan, H.; Yang, Q.; Bai, F.; Li, Y. New J. Chem. 2018, 42, 827831; b) Qi, M.; Chew, B. K. J.; Yee, K. G.; Zhang, Z.-X.; Young, D. J.; Hor, T. S. A. RSC Advances 2016, 6, 23686-23692.

24. a) Wasilke, J.-C.; Obrey, S. J.; Baker, R. T.; Bazan, G. C. Chem. Rev. 2005, 105, 1001-1020; b) Lohr, T. L.; Marks, T. J. Nature Chemistry 2015, 7, 477.

25. a) Rostovtsev, V. V.; Green, L. G.; Fokin, V. V.; Sharpless, K. B. Angew. Chem. 2002, 114, 2708-2711; b) Rostovtsev, V. V.; Green, L. G.; Fokin, V. V.; Sharpless, K. B. Angew. Chem. Int. Ed. 2002, 41, 2596-2599; c) Tornøe, C. W.; Christensen, C.; Meldal, M. The Journal of Organic Chemistry 2002, 67, 3057-3064.

26. Kolb, H. C.; Finn, M. G.; Sharpless, K. B. Angew. Chem. Int. Ed. 2001, 40, 2004.

27. a) Gheorghe, A.; Matsuno, A.; Reiser, O. Adv. Synth. Catal. 2006, 348, 1016-1020; b) Font, D.; Jimeno, C.; Pericàs, M. A. Org. Lett. 2006, 8, 4653-4655; c) Font, D.; Sayalero, S.; Bastero, A.; Jimeno, C.; Pericàs, M. A. Org. Lett. 2008, 10, 337-340; d) Tilliet, M.; Lundgren, S.; Moberg, C.; Levacher, V. Adv. Synth. Catal. 2007, 349, 2079-2084; e) Fernandes, A. E.; Jonas, A. M.; Riant, O. Tetrahedron 2014, 70, 1709-1731.

28. a) Lagunas, A.; Jimeno, C.; Font, D.; Solà, L.; Pericàs, M. A. Langmuir 2006, 22, 3823-3829; b) Lagunas, A.; Mairata i Payeras, A.; Jimeno, C.; Puntes, V. F.; Pericàs, M. A. Chem. Mater. 2008, 20, 92-100; c) Michalek, F.; Lagunas, A.; Jimeno, C.; Pericàs, M. A. J. Mater. Chem. 2008, 18, 4692-4697; d) Eichenseer, C. M.; Kastl, B.; 
Pericàs, M. A.; Hanson, P. R.; Reiser, O. ACS Sustainable Chemistry \& Engineering 2016, 4, 2698-2705; e) Roy, S.; Pericas, M. A. Org. Biomol. Chem. 2009, 7, 2669-2677.

29. a) Vaquer, L.; Riente, P.; Sala, X.; Jansat, S.; Benet-

Buchholz, J.; Llobet, A.; Pericas, M. A. Catalysis Science \& Technology 2013, 3, 706-714; b) Mak, C. A.; Ranjbar, S.; Riente, P.; Rodríguez-Escrich, C.; Pericàs, M. A. Tetrahedron 2014, 70, 6169-6173.

30. Shen, L.; Laibinis, P. E.; Hatton, T. A. Langmuir 1999, 15, 447-453.

31. a) Bradley, C. A.; Yuhas, B. D.; McMurdo, M. J.; Tilley, T. D. Chem. Mater. 2009, 21, 174-185; b) Paoprasert, P.; Spalenka, J. W.; Peterson, D. L.; Ruther, R. E.; Hamers, R. J.; Evans, P. G.; Gopalan, P. J. Mater. Chem. 2010, 20, 2651-2658; c) De Palma, R.; Peeters, S.; Van Bael, M. J.; Van den Rul, H.; Bonroy, K.; Laureyn, W.; Mullens, J.; Borghs, G.; Maes, G. Chem. Mater. 2007, 19, 1821-1831.

32. a) Byun, H.-S.; Zhong, N.; Bittman, R. Organic Syntheses 2000, 77, 225; b) Guo, Z. M.; Jin, Y.; Liang, T.; Liu, Y. F.; Xu, Q.; Liang, X. M.; Lei, A. W. J. Chromatogr. A 2009, 1216, 257-263.

33. a) Hayashi, Y.; Sumiya, T.; Takahashi, J.; Gotoh, H.; Urushima, T.; Shoji, M. Angew. Chem. 2006, 118, 972975; b) Hayashi, Y.; Sumiya, T.; Takahashi, J.; Gotoh, H.; Urushima, T.; Shoji, M. Angew. Chem. Int. Ed. 2006, $45,958-961$ 